\title{
Indeks schematów rówieśników szkolnych uczniów z lekką niepełnosprawnością intelektualną (IE-PP-R) - eksperymentalna wersja kwestionariusza
}

\begin{abstract}
The goal of the paper is presentation the index-measure concerning the classmates-schemes of adolescents' with mild intellectual disabilities (mid). Psychosocial paradigm in rehabilitation inclines to get acquainted with subjective perspective which encourages to compiling instruments matched to cognitive abilities and social experience of the population. The theoretical approach of the tool is: the Theory of Social Schemes by B. Wojciszke (1986). The essence of these schemes is to see others as acting intentionally. As a key of partnerships (with classmates) there were distinguished two dimensions: help - bullying and inclusion - isolation which are very common presented in objective research perspective on mid. Due to the limited cognitive abilities of this population the research tool are based on Likert-type scale reduced to 4 options of choice. Moreover the items are formulated in easy-language based on real episodes. The psychometric procedure included such steps as: preparing a set of items focusing on these experiences, estimation of the content adequacy (by 6 Competent Judges). Then a group of 103 students (55 female and 48 male) with Special
\end{abstract}

1 Paweł Kurtek, Instytut Pedagogiki i Psychologii UJK w Kielcach, Polska, kurtekp@ujk. kielce.pl. 
Educational Centre (SOSW) aged 18 to 22 years under the equinumerosity representation of both male and female, and rural and urban milieu were selected. Obtained data (with the Statistica 10 and XL STAT programs) made it possible to prove the theoretical accuracy (by factors analysis) and the internal reliability (by Cronbach Alpha) of the tool. Therefore the index have sufficient psychometric properties and may be used to explore the subjective schemes of classmates with mid.

\section{Key words:}

social experience, social scheme, intellectual disability, factor analysis

\section{WPROWADZENIE - ZAŁOŻENIA TEORETYCZNE}

Psychospołeczny paradygmat rehabilitacji osób z niepełnosprawnością intelektualną akcentuje podmiotowy, subiektywny wymiar funkcjonowania (Kościelska, 1998; Kowalik, 2007; Kurtek, 2009; Schlalock i in., 2007, 2011; Larkin i in., 2013). Istotne zatem staje się poznanie indywidualnych doświadczeń życiowych zorganizowanych w postaci osobistych schematów poznawczych. Szczególne miejsce w okresie adolescencji zajmują konstrukty dotyczące rówieśników z przestrzeni klasy szkolnej. Dotychczasowe doniesienia badawcze uwzględniające subiektywną perspektywę uczniów wskazują na różnorodność tych doświadczeń. Typ szkolnictwa (włączające vs specjalne) stanowi najczęściej eksplorowany czynnik modyfikujący jakość relacji z rówieśnikami. Omawiana populacja narażona jest, szczególnie w szkolnictwie włączającym, na przemoc rówieśniczą (Mikrut, 2004, 2007), a także doświadcza różnych postaci odrzucenia i osamotnienia (Lipińska-Lokś, 2003; Chodkowska, 2004; Rudek, 2005; Stelter, 2009). Natomiast około 80\% uczniów zasadniczych szkół specjalnych deklaruje doświadczenie wzajemnej pomocy i życzliwości w kontaktach koleżeńskich (Olszewski, 2005). Nie przesądzając jednoznacznie o wartości wspomnianych środowisk, należy wskazać, iż analizy zarówno opisowe, jak i wyjaśniające uwzględniające perspektywę ucznia są słabo reprezentowane w polskim piśmiennictwie. Ma to związek z niedostatkiem na rynku polskim narzędzi badawczych do poznania osobistych schematów dotyczących rówieśników, uwzględniających specyficzne możliwości poznawcze i zakres doświadczeń społecznych młodzieży z lni. Opracowanie narzędzia badawczego wymagało przyjęcia określonych założeń teoretycznych, obiektywizacji procedury badawczej oraz weryfikacji kryteriów dobroci psychometrycznej (Brzeziński, 2003). 
W literaturze przedmiotu można znaleźć klasyfikacje akcentujące różne aspekty (formalne i treściowe) organizacji ludzkiej wiedzy. Należy do nich m.in. poziom obiektywności, złożoności, otwartości, abstrakcyjności, operatywności, uświadomienia (Kozielecki, 1986; Brzeziński, 2003). Istotne miejsce wśród osobistej wiedzy o świecie zajmują schematy osób znaczących. Zgodnie z Teorią Schematów Społecznych sformułowaną przez B. Wojciszke (1986) wiedza o innych zorganizowana jest w formie schematów: przedmiotowych, skryptowych i atrybutywnych. Pierwsze akcentują specyficzną przynależność obiektów, drugie - ich charakterystyczne zachowania, zaś trzecie - właściwości, cechy. Istotnym elementem schematów osób (grup) są specyficzne działania intencjonalne (w odróżnieniu od incydentalnych zdarzeń). Powtarzalność epizodów, zachowań konkretnych osób skłania jednostkę do formowania wiedzy uogólnionej, przyjmującej postać schematu poznawczego (typu skryptowego). Konstrukt ten stanowi zatem „organizację naszych uprzednich doświadczeń z jakimś rodzajem zdarzeń, osób czy obiektów” (Bartlett, za: Wojciszke, 2005, s. 28). Schemat pozbawiony jest elementów konkretnych i incydentalnych na rzecz zgeneralizowanych. A zatem powtarzalne epizody zachowań np. własnej matki formują sieć przekonań i oczekiwań wobec niej („wiem, czego się mogę po niej spodziewać, a czego nie”). Oczywiście heurystyki te mają charakter prawdopodobny, a nie pewny ${ }^{2}$.

Schematy społeczne mają dwa aspekty: deskryptywny i ewaluatywny. Każda tożsamość, zachowanie czy cecha mogą być analizowane pod kątem poznawczego (treściowego) i afektywnego znaczenia. Tym samym treściom obiektywnym można nadawać różne oceny, np. przeciwne znaczenie ewaluatywne zawarte jest w określeniach: skryty - powściągliwy, choć obiektywna cecha małomówności łączy obie atrybucje. Podobną różnicę afektywną przy podobieństwie deskryptywnym wyrażają cechy: gaduła - rozmowny, nieufny - ostrożny, bystry - przemądrzały, maleństwo - kurdupel, upośledzony - niepełnosprawny. Tak więc każdy schemat stanowi nie tylko formę opisu, ale także wartościowania właściwości czy działań obiektu.

Wiedza o innych może opierać się na bezpośrednim doświadczeniu jednostki, kontaktach z konkretnymi osobami, przedstawicielami grup lub na przekazie, pośrednim (społeczno-kulturowym) i przybierać postać uniwersalnych dla danego środowiska stereotypów. Indywidualne, bezpośrednie doświadczenia interpersonalne stanowią bazę dla wiedzy autobiograficznej. Jej matrycą są konkretne

2 Z uwagi na zmienność funkcjonowania człowieka schematy dotyczące innych narażone są na zawodność. Przewidywalność zachowania drugiego człowieka ma charakter probabilistyczny, a nie pewny. 
czasoprzestrzenne epizody dotyczące relacji z innymi. Natomiast drugi system reprezentacji świata społecznego opiera się głównie na przekazie językowym i formuje uogólnioną wiedzę semantyczną jednostki. Rozróżnienie obu systemów wiedzy odwołuje się do koncepcji pamięci semantycznej i epizodycznej E. Tulvinga (1985).

Opisywane narzędzie służyć ma eksploracji wybranych deskryptywno-ewaluatywnych wymiarów schematów opartych na autobiograficznych, epizodycznych, bezpośrednich relacjach z rówieśnikami z klasy szkolnej ${ }^{3}$. Za szczególnie istotny uznano poziom reprezentowanego doświadczenia: bliskości lub izolacji oraz przemocy lub pomocy ze strony rówieśników szkolnych. Reprezentacja izolacji (typu „od”) ze strony rówieśników ujawnia się w postaci przekonań o działaniach ignorujących, izolujących badanego, zaś schemat bliskości (typu „do”) formują czynności: nawiązywania, podtrzymywania i pielęgnowania kontaktu interpersonalnego z badanym. Analogicznie reprezentacja rówieśników jako aktywizujących przemoc ujawnia się w działaniach poniżających (typu „przeciwko”), zaś schemat pomocy (typu „dla”) opiera się na zachowaniach ukierunkowanych na wsparcie emocjonalne lub instrumentalne badanego.

\section{KONSTRUKCJA NARZĘDZIA}

\section{2a. ZAŁOŻENIA FORMALNE - DOSTOSOWANIE KWESTIONARIUSZA DO MOŻLIWOŚCI POZNAWCZYCH MŁODZIEŻY Z LNI}

Przyjęte założenia teoretyczne pozwoliły rozpocząć prace nad opracowaniem wstępnej puli pozycji reprezentujących wybrane aspekty schematów innych. Itemy zawarte w narzędziu mają charakter równoważny, dlatego wchodzą w skład indeksu, a nie skali, która akcentuje zróżnicowane wagi różnych twierdzeń. W konstruowaniu ich uwzględniono zalecenia dotyczące ograniczeń funkcjonowania poznawczego, a w szczególności: słabej techniki czytania, trudności w czytaniu ze zrozumieniem, ograniczonego wglądu we własne opinie, niedorozwoju myślenia na pojęciach abstrakcyjnych (Otrębski, Wiącek, 2011). W związku z tym opisy zastosowane w indeksie zbudowane są z pojedynczych zdań twierdzących, opartych na pojęciach konkretnych, wykorzystywanych w codziennej, potocznej komunikacji. Zrezygnowano natomiast ze stosowania zdań przeczących oraz pojęć abstrakcyjnych. W budowaniu itemów wykorzystywano podstawowe formy czasowników

3 Przyjęto założenie o uniwersalnym znaczeniu tych osób jako znaczących w życiu adolescenta. 
i rzeczowników, odzwierciedlające obserwowalne zachowania rówieśników wobec badanego ucznia z klasy szkolnej. Projektowany kwestionariusz koncentrował się na poznaniu nie ogólnych opinii, lecz schematów poznawczych konkretnych, powtarzalnych działań innych wobec podmiotu. W uwagi na ograniczenia poznawcze w zakresie wydolności uwagi dowolnej minimalizowano także ilość itemów do wielkości niezbędnej. Ponadto z uwagi na ograniczone zdolności poznawcze badanych w zakresie zarządzania pamięcią trudności wglądu oraz możliwy opór w ekspresji własnych doświadczeń (szczególnie negatywnych) zdecydowano się na skonstruowanie narzędzia zamkniętego z określonym repertuarem działań innych wobec badanego (rozpoznawanie stanowi bowiem najprostszą formę odtwarzania danych). Aby uwzględnić ograniczony zakres pamięci operacyjnej młodzieży z lni, związany z zakłóceniami kodowania i aktywnego podtrzymywania informacji w pętli artykulacyjnej (Detterman i in., 2000), kafeterię odpowiedzi sprowadzono do 4 alternatyw częstości określonego działania innych wobec badanego: Zawsze, Często, Rzadko i Nigdy ${ }^{4}$. Natomiast, aby przeciwdziałać tendencji do schematycznego wyboru odpowiedzi, itemy przybierały zarówno postać negatywnych, jak i pozytywnych doświadczeń w zakresie wyodrębnionych wymiarów.

\section{2b. ANALIZA WSKAŹNIKÓW DOBROCI PSYCHOMETRYCZNEJ}

Analiza psychometryczna obejmowała weryfikację poziomu trafności treściowej itemów, trafności teoretycznej przyjętego modelu schematów społecznych oraz rzetelności wyodrębnionych czynników. Trafność teoretyczna, która implikuje zarówno trafność kryterialną, jak i treściową, ma szczególnie istotne znaczenie dla oceny adekwatności między postulowanym i mierzonym zjawiskiem (por. Brzeziński, 2003, s. 411). Specyfiką indywidualnych schematów przedmiotowych (osób lub grup) są zachowania, tzn. rdzeniem każdego osobistego obrazu drugiego człowieka są jego celowe działania (Zuckerman, 1979; Wojciszke, 1986; Maruszewski, 2005). Dlatego narzędzie obejmuje pozycje dotyczące reprezentacji poznawczej pozytywnych i negatywnych działań ukierunkowanych na: przemoc, pomoc, izolację oraz bliski kontakt ze strony rówieśników z klasy szkolnej.

Na podstawie analizy literatury i stosownie do specyfiki doświadczeń okresu dojrzewania opracowano powiększony zestaw 38 itemów opisujących zachowania kolegów wobec badanego, aby w wersji ostatecznej przyjąć najlepsze psychome-

4 Podobną strategię badawczą zastosowali P. Willner i in. (2005), oceniając częstość określonych działań zaradczych w badaniu osób z niepełnosprawnością intelektualną, oraz P. Bramston i J. Bostock (1994), oceniając nasilenie sytuacji stresowych tych osób. 
trycznie pozycje (MacCallum i in., 1999; Fabrigar i in., 1999). Wstępny zestaw itemów poddano analizie treściowej sześciu Sędziom Kompetentnym (pracownikom naukowych - specjalistom pedagogiki lub psychologii). Ich zadaniem było zakwalifikowanie określonego działania rówieśników szkolnych do jednej z czterech kategorii działań podanych powyżej. Ocena poziomu zgodności między nimi została zweryfikowana z wykorzystaniem Testu różnicy proporcji niezależnych (Ferguson, Takane, 2002, s. 218). Jako kryterium proporcji teoretycznej przyjęto wartość 1/4, z uwagi na liczebność kafeterii wyboru kategorii działań. Porównanie empirycznej proporcji ocen zgodnych do wspomnianego kryterium teoretycznego (ustalonego w oparciu o rachunek prawdopodobieństwa) pozwoliło ustalić poziom istotność różnicy tych proporcji. Do pilotażowej wersji indeksów przyjęto tylko te pozycje, dla których proporcja zgodności empirycznej między Sędziami wyniosła 5/6 (co odpowiada wartościom: $z=1,84 ; p=0,07$ ) i 6/6 (co odpowiada wartościom: $z=2,53 ; p=0,01$ ). Pozostałe itemy zostały odrzucone, jako nietrafne treściowo ${ }^{5}$.

Tak przygotowany indeks został wykorzystany w badaniach pilotażowych, dzięki którym możliwa była weryfikacja trafności teoretycznej narzędzia. Do grupy badawczej zakwalifikowano 55 dziewcząt i 48 chłopców, w wieku od 18 do 22 roku życia, o zróżnicowanym pochodzeniu (wiejskim i miejskim). Wszyscy respondenci byli uczniami specjalnej zasadniczej szkoły zawodowej, a ich lekka niepełnosprawność intelektualna została zdiagnozowana dwukrotnie w trakcie kariery edukacyjnej. Realizacja badań została poprzedzona uzyskaniem zgody respondentów na uczestnictwo w badaniu i możliwość wycofania się na każdym etapie procesu zbierania danych (pełnoletniość badanych zwalnia z konieczności uzyskania zgody od Opiekunów).

Wielkość próby pilotażowej zależeć powinna od ilości itemów kwestionariusza. Badacze różnią się w zakresie minimalnej wielkości tej proporcji. Niektórzy sugerują 10 uczestników na każdy item (Nunnally, 1978; Child, 1990), inni dopuszczają niższy poziom proporcji: 5/1 (Gorsuch, 1983; Tabachnick, Fidell, 1989), a nawet 3/1 (Kline,1993). Z uwagi na ograniczony dostęp do grupy badawczej zdecydowano się na poziom proporcji: 3 osoby na 1 item. W konsekwencji czego dobrana grupa badawcza liczyła 103 osoby, a zestaw pozycji w indeksie schematów kolegów z klasy wyniósł 34 itemy.

Standaryzacja narzędzia wymaga ujednolicenia instrukcji badawczej. Aby uzyskać pożądaną reakcję badanego, sformułowano w oparciu o pojęcia konkretne polecenie oceny częstości różnych działań rówieśników z obecnej klasy szkolnej

5 Z puli 38 itemów odrzucone zostały 4 pozycje (, Wygłupiamy się razem po lekcjach”, „Nie obchodzą ich moje sprawy”, „Nikt mnie nie lubi”, „Lubią moje żarty”). 
wobec badanego. Prośbę o zaznaczenie odpowiedzi zgodnej z prawdą połączono z informacją o pełnej anonimowości badania.

Analiza uzyskanych wyników umożliwiła weryfikację trafności teoretycznej i rzetelności narzędzia. Aby zweryfikować trafność teoretyczną przyjętego modelu schematów kolegów u młodzieży z lni zastosowano analizę czynnikową. Wybór odpowiedniego rodzaju rotacji (ortogonalnej lub ukośnej) wynika z oczekiwanych zależności między czynnikami (Child, 1990). Aby sprawdzić empirycznie te zależności, zastosowano Hierarchiczną Analizę Czynnikową, gdyż obserwacja pierwotnych i wtórnych ładunków czynnikowych uprawnia do stosownej decyzji ${ }^{6}$. Interesujące z tej perspektywy wyniki zaprezentowano w tabeli 1.

Tab. 1. Wyniki analizy czynnikowej schematów rówieśników z klasy u młodzieży z Ini

\begin{tabular}{|c|c|c|c|c|c|}
\hline \multirow[b]{2}{*}{ Itemy* } & \multicolumn{2}{|c|}{$\begin{array}{c}\text { Rotacja ukośna typu } \\
\text { Oblimin } \\
\text { (Wyboldowane ładunki z największym } \\
\text { kwadratem cosinusa) }\end{array}$} & \multicolumn{3}{|c|}{$\begin{array}{l}\text { Hierarchiczna analiza czynnikowa } \\
\text { (Wyboldowane ładunki }>0,5 \text { ) }\end{array}$} \\
\hline & Czynnik 1 & Czynnik 2 & $\begin{array}{c}\text { Ladunki } \\
\text { pierwotne } 1\end{array}$ & $\begin{array}{c}\text { Ładunki } \\
\text { pierwotne } 2\end{array}$ & $\begin{array}{l}\text { Ladunki } \\
\text { wtórne }\end{array}$ \\
\hline b-i1 & 0,626 & 0,153 & 0,485 & 0,097 & 0,513 \\
\hline b-i2 & 0,815 & $-0,192$ & 0,645 & $-0,183$ & 0,407 \\
\hline b-i3 & 0,689 & 0,086 & 0,535 & 0,043 & 0,509 \\
\hline b-i4 & 0,660 & 0,194 & 0,505 & 0,128 & 0,558 \\
\hline b-i5 & 0,737 & $-0,079$ & 0,584 & $-0,092$ & 0,433 \\
\hline b-i6 & 0,578 & 0,201 & 0,446 & 0,137 & 0,514 \\
\hline b-i7 & 0,644 & $-0,065$ & 0,521 & $-0,085$ & 0,384 \\
\hline b-i8 & 0,743 & 0,082 & 0,573 & 0,037 & 0,538 \\
\hline b-i9 & 0,484 & 0,334 & 0,362 & 0,251 & 0,540 \\
\hline b-i10 & 0,734 & 0,048 & 0,570 & 0,010 & 0,511 \\
\hline b-i11 & 0,070 & 0,392 & 0,025 & 0,333 & 0,315 \\
\hline b-i12 & 0,072 & 0,686 & 0,017 & 0,546 & 0,496 \\
\hline b-i13 & 0,686 & $-0,066$ & 0,549 & $-0,084$ & 0,409 \\
\hline p-p1 & 0,590 & $-0,084$ & 0,487 & $-0,103$ & 0,338 \\
\hline p-p2 & 0,683 & $-0,042$ & 0,547 & $-0,067$ & 0,423 \\
\hline p-p3 & 0,483 & 0,286 & 0,366 & 0,213 & 0,510 \\
\hline p-p4 & 0,125 & 0,568 & 0,062 & 0,461 & 0,460 \\
\hline
\end{tabular}

6 Analizy rotacji ukośnej (Oblimin) przeprowadzono w oparciu o program XLSTAT 2015.1.01, zaś hierarchiczną analizę czynnikową z wykorzystaniem programu Statistica 10. 


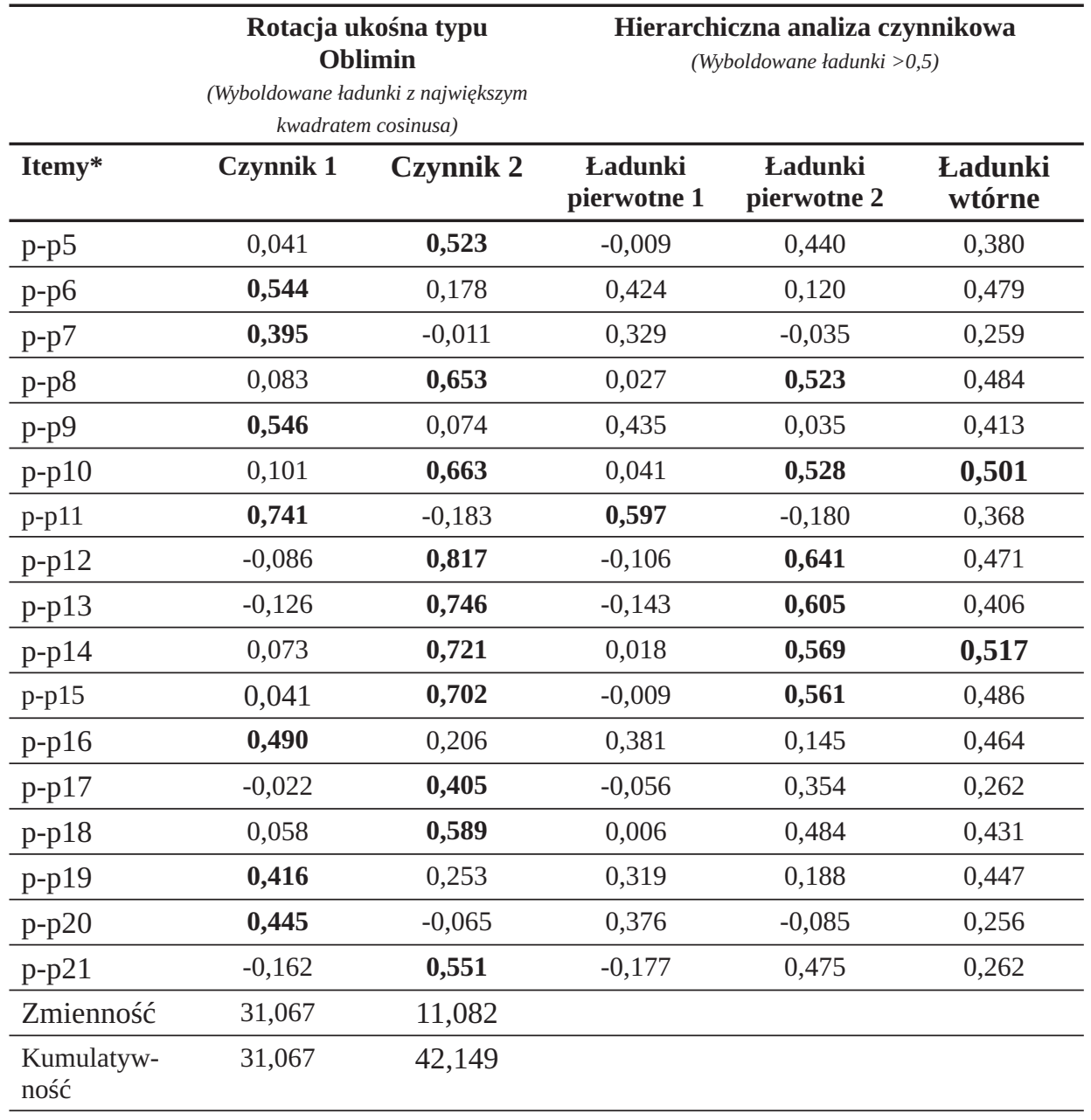

* b-i (wymiar bliskość-izolacja); p-p (wymiar przemoc-pomoc)

Źródło: Opracowanie własne.

Wyniki Hierarchicznej Analizy Czynnikowej wskazują na wariancję wspólną, wyrażoną we wtórnym czynniku, oraz wariancje swoiste dla obu ładunków pierwotnych. Z uwagi na stwierdzone zależności między itemami schematów dotyczących kolegów z klasy zastosowano dodatkowo eksploracyjną analizę czynnikową z rotacją ukośną (typu Oblimin). Pozwoliło to zweryfikować zgodność obu metod w zakresie poziomu ładowania czynników przez poszczególne itemy indeksu. Analiza czynnikowa (osypiska, poziomu zmienności i kumulatywności) wskazuje na dwa wiodące czynniki w zakresie reprezentacji rówieśników z klasy 
szkolnej. Analiza treściowa wskazuje, iż pierwszy czynnik wiąże się z pozytywnymi doświadczeniami, głównie poszukiwania i podtrzymywania bliskości (np. „podchodzą, żeby pogadać”, „wybierają się ze mną na rower”), wsparcia (np. „dają mi ściągnąć na klasówce”), zaś drugi tworzą negatywne schematy, wskazujące na doświadczenie izolacji (np. „na przerwie często stoję sam”) oraz przemocy słownej lub fizycznej (np. „wyśmiewają się ze mnie”, „szukają zaczepki”). Okazało się, że w schemat rówieśników dąży do jednoznaczności (są ok lub nie ok), dominują bowiem pozytywne lub negatywne przejawy zachowań (bez ambiwalencji). Analiza czynnikowa z rotacją nieortogonalną typu Oblimin wskazała na istotne znaczenie każdego itemu dla jednego bądź drugiego czynnika. Natomiast hierarchiczna analiza czynnikowa, przy przyjętym kryterium ładowania czynnika na poziomie wartości 0,5, wskazała na nieco mniejszą pulę ważnych pozycji. Uwzględniając zarówno wyniki analizy trafności treściowej, jak i teoretycznej, za najbardziej istotne dla wymiaru: bliskości-izolacji uznano itemy oznaczone kodem „b-i”: 2, 3, 4, 5, 7, 8, 9, 10, 12, 137. Z kolei świadome doświadczenia dotyczące wymiaru: przemocy-pomocy najwyraźniej ujawniły się w pozycjach oznaczonych kodem „p-p”: 2, 8, 10, 11, 12, 13, 14, 15 i nieco słabiej w twierdzeniach: 7, 16, 17, 18, $21^{8}$.

Wyodrębnione zestawy pozycji stały się podstawą szacowania rzetelności wymienionych obszarów indywidualnych schematów w oparciu o test alpha-Cronbacha. Technika ta nie jest obciążona wpływem uczenia się, pamięci czy zmiennością kontekstu funkcjonowania respondenta. Poziom zgodności wewnętrznej dla zestawu ww. pozycji formujących czynnik: bliskość-izolacja wyniosła 0,90, zaś dla wyodrębnionej puli itemów zasilających czynnik: pomoc-przemoc uzyskała wartość 0,83. Wyniki te potwierdzają jednorodność poszczególnych grup pozycji i uzasadniają ich przydatność badawczą w zakresie wskazanych obszarów reprezentacji rówieśników z klasy szkolnej, przewyższają bowiem minimalny poziom zgodności wewnętrznej - 0,7 (Sveinbjornsdottir, Thorsteinsson, 2008). Przeprowadzona analiza psychometryczna pozwoliła zweryfikować wartość poszczególnych itemów i uzasadnia uznanie indeksu schematów rówieśników klasowych jako narzędzia trafnego i rzetelnego.

7 Zdecydowano się na włączenie itemu b-i9 („Grają ze mną w piłkę lub inne zabawy”) i eliminację twierdzenia b-i1 („Rozmawiają ze mną o różnych sprawach”) z uwagi na większą jednoznaczność i konkretność.

8 Z uwagi na mniejszą reprezentację wymiaru: pomoc-przemoc zdecydowano się na włączenie do dalszych prac nad narzędziem także itemy o niższym poziomie ładowania (0,4): 7, 16, 17, 18, 21 (z kodem - „p-p”), dwa pierwsze związane z doświadczeniem pomocy zaś trzy następne wskazujące na schematy przemocy. Ten wymiar doświadczenia ma bowiem szczególnie negatywny charakter dla dobrostanu jednostki i jego dokładniejsza eksploracja wydaje się szczególnie uzasadniona. 


\section{C. TECHNIKA OBLICZANIA POZIOMU: AKCEPTACJI VS ODRZUCENIA, AUTONOMII VS DOMINACJI, INKLUZJI VS EKSKLUZJI, POMOCY VS PRZEMOCY}

Narzędzie służy do poznania nasilenia doświadczeń pozytywnych (w tym: pomocy i bliskości) oraz negatywnych (w tym: przemocy i izolacji) reprezentowanych w schemacie rówieśników z klasy szkolnej. Ponadto możliwe jest określenie pozycji ucznia na wymiarze: bliskości-izolacji oraz pomocy-przemocy, w oparciu o itemy reprezentujące te doświadczenia. Przyjmuje się, iż każde zachowanie rówieśników, jako grupy znaczącej, ma charakter ewaluatywny, tzn. stanowi podstawę weryfikacji jego wartości, pozycji społecznej. Wyłącza się zatem możliwość zachowań neutralnych. Tym samym brak zachowań pomocowych stanowi przejaw biernej postawy typu „przeciw”, zaś brak nasilenia działań opartych na przemocy wskazuje na pozytywną sytuację ucznia. Analogicznie brak zachowań izolacyjnych ze strony rówieśników pozwala wnioskować o inkluzji badanego w sieć relacji, zaś brak działań z zmierzających do kontaktu wskazuje na marginalizację jednostki.

W konsekwencji czego wyniki surowe dla doświadczeń pozytywnych lub negatywnych obliczane są na podstawie sumy punktów z pozycji diagnostycznych dla danego aspektu schematów wg układu: 0 - Nigdy, 1 - Rzadko, 3 - Często, 4 - Zawsze. Natomiast, aby obliczyć pozycję ucznia na wymiarze: pomoc-przemoc oraz bliskość-izolacja należy zachować powyższą zasadę punktowania dla twierdzeń pozytywnych, zaś odwrócić ją dla itemów negatywnych (tj. 4 - Nigdy, 3 - Rzadko, 1 - Często, 0 - Zawsze). W obliczaniu wyników surowych należy zsumować wartości dla poszczególnych wymiarów wg następującego klucza9:

1. Pozytywne - 1, 2, 3, 4, 5, 7, 9, 10, 12, 14, 15, 18, 20.

2. Negatywne - 6, 8, 11, 13, 16, 17, 19, 21, 22, 23.

3. Inkluzja-Izolacja - 1, 3, 5, 7, 10, 12, 14, 15, 19-, 20.

4. Pomoc-Przemoc - 2, 4, 6-, 8-, 9, 11-, 13-, 16-, 17-, 18, 21-, 22-, 23.

(Wskaźnik ,-” oznacza item negatywny, odwrotnie punktowany).

Aby przeciwdziałać skłonności do uśredniania, unikania jednoznaczności w ocenie innych, nie włączono do kafeterii odpowiedzi kategorii „Czasem”. Dostrzegalna tym samym przerwa w stopniowaniu częstości określonego działania znajduje swoje odzwierciedlenie w wartości punktowej poszczególnych odpowie-

9 Numery itemów odnoszą się do zaakceptowanych w wyniku analizy trafności i rzetelności wersji zestawu indeksów zamieszczonych w załącznikach. 
dzi (zrezygnowano z wartości - 2 adekwatnej dla odpowiedzi „Czasem”). Ogólny wskaźnik ilościowy dla określonego wymiaru schematu waha się w granicach: od 0 do 4 razy $\mathrm{n}^{10}$.

\section{PODSUMOWANIE}

Uzyskane wyniki wskazują, iż Indeks schematów rówieśników szkolnych (IE-PP-R) spełnia podstawowe kryteria dobroci psychometrycznej i może stanowić podstawę ilościowych i jakościowych analiz idiograficznych oraz nomotetycznych, w tym porównań międzygrupowych w badaniach naukowych dotyczących doświadczeń młodzieży z lni. Choć badania były prowadzone z udziałem uczniów szkolnictwa specjalnego, to przyjęte w konstrukcji narzędzia wymiary mają charakter uniwersalny, co upoważnia do stosowania indeksu także w innych placówkach edukacyjnych (nie byłoby to zasadne w przypadku opracowania itemów sformułowanych samodzielnie przez badanych w oparciu o technikę swobodnego opisu własnych doświadczeń). Zaproponowane narzędzie umożliwia zatem eksplorację pozytywnych (bliskości i pomocy) i negatywnych (przemocy i izolacji) elementów zachowań rówieśników z klasy szkolnej odzwierciedlonych w schematach poznawczych każdego ucznia z lni od 18 do 22 roku życia.

Uzyskane wyniki skłaniają do wnioskowania, iż system wiedzy osobistej o rówieśnikach dąży do jednoznaczności ewaluacyjnej, gdyż badane wymiary doświadczeń (inkluzji i pomocy oraz izolacji i przemocy) okazały się względnie zależne w systemie osobistej wiedzy młodzieży z lni o rówieśnikach z przestrzeni klasy szkolnej. Wniknięcie w ten subiektywny obszar relacji z rówieśnikami ucznia z lni stanowi ciekawe wyzwanie badawcze, ale ma także istotne znaczenie dla praktyki edukacyjno-rehabilitacyjnej. Znajduje to swoje potwierdzenie w najnowszych zapowiedziach klasyfikacyjnych DSM-V (rekomendowanych przez American Association on Intellectual and Developmental Disabilities - AAIDD), akcentujących społeczne i podmiotowe aspekty funkcjonowania osób z niepełnosprawnoscią intlektualną (Schlalock i in., 2007, 2010). Uzupełnienie perspektywy społecznej (zorientowanej na badanie postaw wobec osób niepełnosprawnych) o subiektywną podmiotową optykę postrzegania innych pozwala trafniej opisywać przestrzeń relacji międzyludzkich.

10 n - oznacza ilość itemów dla danego aspektu schematu. 
Choć w świetle przedstawionych analiz opisane narzędzie rokuje pozytywnie w zakresie dobroci psychometrycznej, to wymaga dalszych czynności standaryzacyjnych na większej próbie badanych. Planowane działania normalizacyjne na stosownej reprezentacji pozwolą na bardziej obiektywną ocenę doświadczeń społecznych oraz precyzyjniejszą interpretację indywidualnych wyników surowych.

\section{Literatura:}

Bramston, P., Bostock, J. (1994). Measuring stress in people with intellectual disability: The development of a new scale. Australia and New Zealand Journal of Developmental Disabilities, 19, s. 149-157.

Brzeziński, J. (2003). Poznanie naukowe - poznanie psychologiczne. W: J. Strelau (red.), Psychologia. Podręcznik akademicki. Podstawy psychologii (s. 335-354). Gdańsk: GWP Gdańskie Wydawnictwo Psychologiczne.

Brzeziński, J. (2003). Teoria testów psychologicznych: ABC psychometrii, W: J. Strelau (red.). Psychologia. Podręcznik akademicki. Podstawy psychologii (s. 400-415). Gdańsk: GWP Gdańskie Wydawnictwo Psychologiczne.

Child, D. (1990). The essentials of factor analysis, London: Holt, Rinehart and Winston. Chodkowska, M. (2004). Socjopedagogiczne problemy edukacji integracyjnej dzieci z obciążeniami biologicznymi i środowiskowymi, Warszawa: Wydawnictwo WSP TWP.

Fabrigar, L., Wegener, D., MacCallum, R., Strahn, E. (1999). Evaluating the use of exploratory factor analysis in psychological research. Psychological Methods, 4, s. 272-299.

Ferguson, G., Takane, Y. (2002). Analiza statystyczna i psychologii i pedagogice. Warszawa: Wydawnictwo Naukowe PWN.

Gorsuch, R. (1983). Factor analysis. Hillsdale, NJ: Erlbaum.

Harter, S. (1988). The Self-Perception Profile for Adolescents. Denver: University of Denver.

Kościelska, M. (1998). Oblicza upośledzenia. Warszawa: PWN.

Kowalik, S. (2007). Psychologia rehabilitacji. Warszawa: WAiP.

Kozielecki, J. (1986). Psychologiczna teoria samowiedzy. Warszawa: PWN.

Kravetz, S., Katz, S., Alfa-Roller, I., Yehoshua, S. (2003). Aspects of a Theory of Mind and Self-Reports of Quality of Life by Persons with Mental Retardation. Journal of Developmental \& Physical Disabilities, 15 (2), s. 165-183.

Kurtek, P. (2009). Młodzież z niepełnosprawnością intelektualną w stopniu lekkim wobec sytuacji trudnych. Osobowościowe i sytuacyjne uwarunkowania radzenia sobie. Kielce: Wydawnictwo Uniwersytetu Humanistyczno-Przyrodniczego Jana Kochanowskiego.

Larkin, P., Jahoda, A., MacMahon, K. (2013). The Social Information Processing Model as a Framework for Explaining Frequent Aggression in Adults with Mild to moderate Intellectual Disabilities: A Systematic Review of the Evidence. Journal of Applied Research in Intellectual Disabilities, 26 (5), s. 447-465.

Lipińska-Lokś, J. (2003). Psychospołeczna sytuacja dzieci z niepełnosprawnością intelektualną w klasach integracyjnych. W: Z. Janiszewska-Nieścioruk (red.), Człowiek z niepełnosprawnością intelektualną (s. 249-256). Kraków: Oficyna Wydawnicza Impuls. 
MacCallum, R.C., Widaman, K.F., Zhang, S., Hong, S. (1999). Sample size in factor analysis. Psychological Methods, 4, s. 84-99.

Maruszewski, T. (2005). Pamięć autobiograficzna. Gdańsk: Gdańskie Wydawnictwo Psychologiczne.

Mikrut, A. (2004). Poczucie bezpieczeństwa a agresywność uczniów z lekkim upośledzeniem umysłowym. Szkoła Specjalna, 4, s. 273-285.

Mikrut, A. (2007). Stygmat „Upośledzenie Umysłowe” a ryzyko zostania ofiarą przemocy. Szkoła Specjalna, 3, s. 184-191.

Nunnally, J. (1978). Psychometric theory. New York: McGraw-Hill.

Olszewski, S. (2005). Postrzeganie przestrzeni życiowej przez młodzież z niepełnosprawnością intelektualną w kontekście zachowań agresywnych. Kraków: Wydawnictwo Naukowe Akademii Pedagogicznej.

Otrębski, W., Wiącek, G. (2011). Diagnostyka w rehabilitacji zawodowej osób z niepełnosprawnością umysłową - uzasadnienie teoretyczne dla konstrukcji narzędzi. Przegląd Psychologiczny, 54 (4), s. 401-424.

Plopa, M. (2005). Psychologia rodziny. Teoria i badania. Kraków: Oficyna Wydawnicza Impuls.

Rudek, I. (2005). Tolerancja dzieci wobec niepełnosprawnych rówieśników. Auxilium Socjale. Wsparcie Społeczne, 1, s. 65-76.

Schlalock, R., Borthwick-Duffy, S., Buntinx, W., Coulter, D., Craig, E. (2010). Intellectual disability. Definition, classification, and system of support. 11th edition. Washington: American Association on Intellectual and Developmental Disabilities.

Schlalock, R., Luckasson, R., Shogren, K. (2007). Perspectives. The Renaming of Mental Retardation: Understanding the Change to the Term Intellectual Disability. Intellectual and Developmental Disabilities, 45 (2), s. 116-124.

Stelter, Ż. (2009). Dorastanie osób z niepełnosprawnością intelektualną. Warszawa: Scholar.

Sveinbjornsdottir, S., Thorsteinsson, E. (2008). Adolescent coping scales: A critical psychometric review. Scandinavian Journal of Psychology, 49, s. 533-548.

Tabachnick, B.G., Fidell, L.S. (1989). Using multivariate statistics. New York: HarperCollins.

Tulving, E. (1985). How many memory systems are there? American Psychologist, 40, s. 385-398.

Willner, P., Brace, N., Phillips, J. (2005). Assessment of anger coping skills in individuals with intellectual disabilities. Journal of Intellectual Disability Research, 49 (5), s. 329-339.

Wojciszke, B. (1986). Teoria schematów społecznych. Struktura i funkcjonowanie jednostkowej wiedzy o otoczeniu społecznym. Wrocław-Warszawa-Kraków-Gdańsk-Łódź: WDNSK.

Wojciszke, B. (2005). Postawy i ich zmiana. W: J. Strelau (red.), Psychologia. Podręcznik akademicki. Jednostka w społeczeństwie i elementy psychologii stosowanej. Gdańsk: Gdańskie Wydawnictwo Psychologiczne.

Zuckerman, M. (1979). Attribution of success and failure revisited, or: The motivational bias is alive and well in attribution theory. Journal of Personality, 47, s. 245-287. 